Article

\title{
The influence of knowledge and perceptions of doctors on the quality of medical records
}

\author{
Nining Dwi Suti Ismawati, ${ }^{1,2}$ Stefanus Supriyanto, ${ }^{3}$ Setya Haksama, ${ }^{3}$ Cholicul Hadi ${ }^{4}$ \\ ${ }^{1}$ Doctoral Program of Public Health, Faculty of Public Health, Universitas Airlangga, Surabaya; ${ }^{2}$ Dr. Soetomo \\ General and Academical Hospital, Surabaya; ${ }^{3}$ Health Policy and Administration Department, Faculty of Public \\ Health, Universitas Airlangga, Surabaya; ${ }^{4}$ Faculty of Psychology, Universitas Airlangga, Surabaya, Indonesia
}

\begin{abstract}
Background: Medical record reflects the quality of health services provided, which is influenced by existing resources, such as the doctors in charge. This study aims to determine whether doctors' knowledge and perceptions affect the quality of the medical record.

Design and Methods: This is a quantitative and cross-sectional study carried out at Dr. Soetomo's general and academic hospital Surabaya, Indonesia, in September and October 2020. Data were purposively obtained from a total of 45 doctors working at the hospital's inpatient service surgery ward using the questionnaire and checklist medical record quality. Furthermore, ethical clearance and doctors' informed consent were obtained, with the data statistically processed and analyzed by multiple linear regressions.

Results: The results and conclusion showed that doctors' knowledge and perceptions of the quality of medical records were influence to medical record quality $(\mathrm{p}<0.05)$.

Conclusions: Hospital management needs to regularly increase doctors' knowledge and perceptions by socializing and monitoring medical records.
\end{abstract}

\section{Introduction}

A medical record is a tool used by health workers to investigate or study previous medical treatment history and understand the established diagnosis for further evaluation and treatment. Good medical record keeping is important for patients to receive appropriate and continuous medical care and defend doctors facing malpractice accusations. ${ }^{1}$ Medical record service is a professional support service activity oriented to the needs of health providers, administrators, and management facilities. ${ }^{2}$ The existence of a medical record unit in a hospital acts as a data collection and processing center to present health information for internal and external users. ${ }^{3}$ One of the components of health services used to determine its quality in hospitals is the availability of data/ information from medical records. According to law No. 269 of 2008 concerning medical records, health workers are mandated to record patient data as evidence of medical services. The interac- tion and utilization of hospital resources are driven through certain processes and procedures capable of affecting good medical records quality. It comprises complete, accurate, timely, clear, and valid data that meet the legal aspects needed to support hospital health services. ${ }^{4}$

Professional employees with high performance are obtained by empowering the concept of engagement, as a concept and way of working, designed to ensure they are committed to the organization's goals and values. Furthermore, they are motivated to contribute to the success of the organization and increase the sense of self welfare. ${ }^{5}$ Doctors with knowledge of the medical record have the ability to completely and properly fill patients' documents. ${ }^{6}$ Their performance in health services can also be traced through medical records, which are influenced by several factors, motivation, leadership, organization, and word culture. ${ }^{7,8}$ However, the report on the completeness of Dr. Soetomo Hospital's medical records from 2017 - 2019 were incomplete, unclear, inaccurate, and unable to match the quality standard. The completeness figure's achievement in 2017, 2018, and 2019 were $47.86 \%, 68.69 \%$, and $80.62 \%$. Therefore, this study aims to prove the influence of doctors' knowledge and perceptions in filling out medical records as a professional employee.

\section{Design and Methods}

This is a quantitative and cross-sectional study carried out at Dr. Soetomo general and academic hospital, Surabaya, Indonesia, in September and October 2020. The population and sample comprise 141 doctors working in surgery wards, with 45 doctors purposively selected for this research. The dependent variables were medical records quality. The independent variables were the knowledge and perceptions of doctors, with data collected by questionnaire and checklist medical record quality. The questionnaire contains 13 questions of knowledge and perceptions each. The medical record quality checklist was carried out on 90 documents after obtaining ethical clearance and doctors' consent. Furthermore, the data were processed and analyzed statistically by multiple linear regressions.

Significance for public health

The medical record is the benchmark, and an important instrument used to support health services. Therefore, this paper describes the influence of doctors' knowledge and their perceptions on the quality of medical records. 


\section{Results and Discussions}

In this study, the influence of the independent variables [knowledge $\left(\mathrm{X}_{1}\right)$ and perception $\left(\mathrm{X}_{2}\right)$ ] on the dependent variable (quality of medical records (Y)) was analyzed simultaneously using multiple linear regression tests that showed in Table 1 . The results of the analysis showed that knowledge and perception had a significant effect on the quality of medical records with p-value $<0.05$. The significance value of $X_{1}$ and $X_{2}$ are 0.030 and 0.000 , respectively. When viewed from the direction of its influence on the dependent variable, perception has a positive effect on the quality of medical records while knowledge has a negative effect on the quality of medical records. The following is the regression equation model from this study, $\mathrm{Y}=82.270-0.625 \mathrm{X}_{1}+0.426 \mathrm{X}_{2}$.

The influence of the responsible care doctor (DPJP) knowledge and perceptions on the quality of medical records, seen from the results of multiple linear regression analysis, shows that the $\mathrm{R}$ value is 0.564 , which means that the effect of knowledge and perception on the quality of medical records is $56.4 \%$. Coefficient of determination (R-square) is a value used to see the extent to which the model formed can explain the actual conditions. The R-square value from the model is equal to 0.318 , which means that the percentage of the dependent variable (quality of medical records) is $31.8 \%$ influenced by the knowledge and perceptions of doctors about medical records and $68.2 \%$ is influenced by other factors not examined in this study.

Based on the results of the regression model that has been obtained which is $\mathrm{Y}=82,270-0.625 \mathrm{X}_{1}+0.426 \mathrm{X}_{2}$, with a determination coefficient is $31.8 \%$. The constant value of 82.27 means that if the independent variables of knowledge $\left(\mathrm{X}_{1}\right)$ and perception $\left(\mathrm{X}_{2}\right)$ are equal to 0 then the quality of the medical records of $\mathrm{dr}$. Soetomo hospital amounting to 82,270. The coefficient of knowledge is 0.625 and negative means that each value decreases, the quality of medical records decreases by -0.625 and vice versa as long as other variables appear constant. The perception coefficient value is 0.426 and positive means that there is an increase of 1 point of perception, it will increase the quality of medical records by 0.426 as long as other variables appear constant. So it can be ignored that the doctor's perspective is the dominant factor affecting the quality of medical records.

Perception has a significant positive effect on the quality of medical records. A good doctor's perception of medical records improves the quality of medical records. Perception of work, which is the result of examining the five senses of humans in accordance with the condition of the surrounding environment, gives comfort to work and tends to improve performance. ${ }^{9}$ In this study, the perception assessment consisted of a medical record, an assessment of the supervised, monitoring, and evaluation systems. A good perception of the medical record system indicates acceptance, thereby indicating the ability to improve performance. ${ }^{10}$ Perceptions of the usefulness and convenience of the medical record system in either category affect the intention to use the medical record system maximally. ${ }^{11}$ The availability of a short medical record speeds up the document filling process. A study carried out by Setiadani et al. stated that factors affecting the quality of medical records include the availability of materials and machines in stationery forms. ${ }^{12}$ This study showed that without doctors' direct supervision, there is a possibility of obtaining differences in perceptions regarding filling up medical records. The existence of periodic supervision activities tends to maintain service quality in high standard, with the ability to pay attention to service users' characteristics. ${ }^{13-16}$ Superiors or supervisors act as part of the first level of management in charge of controlling performance as well as the quality of health service. ${ }^{17-19}$

In this study, knowledge significantly affects the quality of medical records. Good knowledge will improve the quality of medical records, but there is good knowledge are unable to encourage optimal performance of filling out medical records. This occurs when doctors have a high workload, lack of organizational support and lack of communication. Furthermore, medical record knowledge among doctors can be enhanced through training/workshops. The research carried out on resident doctors reported an increase in the quality of medical record documents after training activities/workshops. ${ }^{20-22}$

A similar study in an Ethiopian hospital stated that the presence of training interventions significantly increased the completeness of filling in medical records..$^{23}$ Dewi and Agustina stated that medical officers' compliance, such as those in charge, is lacking due to their business. Therefore, there is incompleteness in filling up medical records documents. This also means that data, such as signatures, date, time, and complete diagnosis, are sometimes missed or forgotten when filling out documents due to illegible writing. ${ }^{24}$ The difference in knowledge level is one of the reasons for the incomplete filling of medical records. ${ }^{25}$

Table 1. The influence of knowledge and perception on medical records quality multiple linear regression.

\begin{tabular}{|c|c|c|c|c|c|}
\hline Model & \multicolumn{2}{|c|}{ Unstandardized coefficients } & $\begin{array}{c}\text { Coefficient } \\
\text { Standardized coefficients } \\
\text { Beta }\end{array}$ & $\mathrm{t}$ & p-value \\
\hline Constant & 82.270 & 2.688 & & 30.601 & 0.000 \\
\hline Knowledge & -0.625 & 0.278 & -0.386 & -2.245 & 0.030 \\
\hline Perception & 0.426 & 0.098 & 0.744 & 4.334 & 0.000 \\
\hline $\mathbf{R}$ & R square & $\begin{array}{c}\text { Mo } \\
\text { Adjusted R square }\end{array}$ & $\begin{array}{l}\text { ummary } \\
\text { Std. error }\end{array}$ & \multicolumn{2}{|c|}{ Durbin-Watson } \\
\hline 0.564 & 0.318 & 0.285 & 2.49873 & \multicolumn{2}{|c|}{2.231} \\
\hline Model & Sum of squares & Mean square & VA & \multicolumn{2}{|c|}{ p-value } \\
\hline Regression & 122.210 & 61.105 & 9.787 & \multicolumn{2}{|c|}{0.000} \\
\hline Residual & 262.234 & 6.244 & & & \\
\hline
\end{tabular}




\section{Conclusions}

In conclusion, doctors' knowledge and perceptions affect the medical records quality with a significant value less then 0.05 . Furthermore, hospital management needs to increase doctors' knowledge and perceptions by socializing and monitoring medical records' evaluation regularly to study further and determine other visible factors.

Correspondence: Nining Dwi Suti Ismawati, Faculty of Public Health, Universitas Airlangga, Kampus C Mulyorejo, Surabaya 60115, Indonesia. Tel. +62.315920948 - Fax: +62.315924618

E-mail: nining.dwi.suti-2017@fkm.unair.ac.id

Key words: Knowledge; perception; quality of medical records; doctors' performance.

Acknowledgments: The authors are grateful to Dr. Soetomo General Hospital Surabaya, Indonesia, for their support.

Contributions: All authors discussed the results and contributed to the final manuscript, while SS, CH, and SH supervised the study.

Conflict of interest: The authors stated that there is no potential conflict of interest.

Funding: This study was financially supported by Dr. Soetomo General Hospital Surabaya, Indonesia.

Ethics approval: This study was approved by the health research ethics committee of Dr. Soetomo General Hospital Surabaya.

Conference presentation: Part of this study was presented at the $1^{\text {st }}$ International Nursing and Health Sciences Symposium, November $13^{\text {th }}$ to $15^{\text {th }} 2020$, Brawijaya University, Malang, Indonesia.

Received for publication: 16 January 2021.

Accepted for publication: 23 March 2021.

CCopyright: the Author(s), 2021

Licensee PAGEPress, Italy

Journal of Public Health Research 2021;10:2228

doi:10.4081/jphr.2021.2228

This work is licensed under a Creative Commons Attribution NonCommercial 4.0 License (CC BY-NC 4.0).

\section{References}

1. Ngo E, Patel N, Chandrasekaran K, et al. The importance of the medical record: A critical professional responsibility. Med Pract Manag. 2016;305-9.

2. Susanto E, Sugiharto. [Manajemen Informasi Kesehatan IV: Etika Profesi dan Hukum Kesehatan (Health information management IV: Professional ethics and health law)].[Article in Indonesian]. Jakarta: Center for Health Human Resources Education; 2017.

3. Siswati, Maryati Y. [Manajemen Mutu Informasi Kesehatan II: Akreditasi dan Manajemen Resiko (Health information quality management II: Accreditation and risk management)].[Article in Indonesian]. Jakarta: Pusat Pendidikan Sumber Daya Manusia Kesehatan; 2017.

4. Setyawan FEB, Supriyanto S. [Manajemen Rumah Sakit (Hospital management)].[Article in Indonesian]. Sidoarjo:
Zifatama Jawara; 2019.

5. Anitha J. Determinants of employee engagement and their impact on employee performance. Int J Product Perform Manag 2014;63:308-23.

6. Maryati W. [Hubungan Antara Karakteristik Dokter Dengan Kelengkapan Pengisian Lembar Ringkasan Keluar (Relationship between doctor characteristics and completeness of exit summary sheet filling)].[Article in Indonesian]. J Manaj Inf Kesehat Indones 2014;3:26-35.

7. Tanwar A. Impact of employee engagement on performance. Int J Adv Engin Manage Sci 2017;3:510-5.

8. West MA, Dawson JF. Employee engagement and NHS performance. The King's Fund; 2012. Available from: http:/www.kingsfund.org.uk/sites/files/kf/employee-engagement-nhs-performance-west-dawson-leadership-review2012paper.pdf

9. Parsidi, Hendrajaya SW. [Pengaruh Persepsi Kerja dan Motivasi Kerja Terhadap Kinerja Dosen Sekolah Tinggi Pariwisata AMPTA Yogyakarta dengan Kompensasi Kerja sebagai Variabel Moderasi (The influence of work perceptions and work motivation on lecturer performance of the AMPTA Yogyakarta Tourism College with Work compensation as a moderation variable)].[Article in Indonesian]. J Media Wisata 2015;13:328-37.

10. Chirchir LK, Aruasa WK, Chebon SK. Perceived usefulness and ease of use as mediators of health information system on user performance. Eur J Comput Sci Inf Technol 2019;7:2237.

11. Tubaishat A. Perceived usefulness and perceived ease of use of electronic health records among nurses: Application of Technology Acceptance Model. Informatics Heal Soc Care 2018;43:379-89.

12. Setiadani P, Sulaeman ES, Herlambang PM. [Faktor-Faktor yang Berhubungan dengan Mutu Rekam Medis Pasien Rawat Inap di RSUD DR. Moewardi Surakarta (Factors associated with the quality of inpatient medical records at RSUD DR. Moewardi Surakarta)].[Article in Indonesian]. Nexus Kedokt Komunitas 2016;5:54-68.

13. Pribadi A. [Analisis Pengaruh Faktor Pengetahuan, Motivasi, dan Persepsi Perawat Tentang Supervisi Kepala Ruang Terhadap Pelaksanaan Dokumentasi Asuhan Keperawatan di Ruang Rawat Inap RSUD Kelet Provinsi Jawa Tengah di Jepara (Analysis of the influence of knowledge, motivation and perceptions of nurses on supervision of the head of the room on the implementation of nursing care documentation in the inpatient room of Kelet Hospital, Central Java province in Jepara)].[Article in Indonesian]. Semarang: Universitas Diponegoro; 2009.

14. Christino MA, Matson AP, Fischer SA, et al. Paperwork versus patient care: a nationwide survey of residents' perceptions of clinical documentation requirements and patient care. J Grad Med Educ 2013;5:600-4.

15. Snowdon DA, Leggat SG, Taylor NF. Does clinical supervision of healthcare professionals improve effectiveness of care and patient experience? A systematic review. BMC Health Serv Res 2017;17:786.

16. Desta BF, Beshir IA, Tefera BB, et al. Does frequency of supportive supervisory visits influence health service delivery?Dose and response study. PLoS One 2020;15:e0234819.

17. Ghiasipour M, Mosadeghrad AM, Arab M, et al. Leadership challenges in health care organizations: The case of Iranian hospitals. Med J Islam Repub Iran 2017;31:96.

18. Nasiri A, Aryankhesal A, Khankeh H. Leadership in limbo: Characteristics of successful incident commanders in health 
sector of a disaster-prone country. Int J Health Plann Manage 2019;34:e1495-509.

19. Bikmoradi A, Brommels M, Shoghli A, et al. Identifying challenges for academic leadership in medical universities in Iran. Med Educ 2010;44:459-67.

20. Vahedi HS, Mirfakhrai M, Vahidi E, et al. Impact of an educational intervention on medical records documentation. World J Emerg Med 2018;9:44-7.

21. Sayyah-Melli M, Nikravan Mofrad M, Amini A, et al. The Effect of medical recording training on quantity and quality of recording in gynecology residents of Tabriz University of Medical Sciences. J Caring Sci 2017;6:281-92.

22. Ajami S, Ketabi S, Sadeghian A, et al. Improving the medical records department processes by lean management. J Educ
Health Promo 2015;4:48.

23. Tola K, Abebe H, Gebremariam Y, et al. Improving completeness of inpatient medical records in Menelik II Referral Hospital, Addis Ababa, Ethiopia. Adv Public Health 2017;2017:1-5.

24. Dewi NF, Agustina K. [Analissi Sistem Pelayanan Rekam Medis Rawat Inap di RSUP Dr. Kariadi Semarang Tahun 2016 (Analysis of inpatient medical record service systems at Dr. Kariadi Semarang in 2016)].[Article in Indonesian]. J Vokasi Indones 2017;5:29-37.

25. Hariez TM, Mansur M, P ESK. The incompleteness of medical record documents: Causative factor and solution studied on private hospital in Malang City. Int J Sci Res 2018;7:576-80. 